FACTA UNIVERSITATIS

Series: Law and Politics Vol. 17, N ${ }^{\circ} 3,2019$, pp. 209-221

https://doi.org/10.22190/FULP1903209V

Original Scientific Paper

\title{
THE SUBSTANCE AND IMPLICATIONS OF INTEGRAL PLANNING IN LOCAL GOVERNMENT UNITS
}

\author{
UDC 352(497.11) \\ $340.132: 342.25$
}

\section{Igor Vukonjanski}

National Academy of Public Administration, Belgrade, Serbia

\begin{abstract}
Local development planning in local government units (municipalities and towns) has always played an important social role in all countries. In recent decades, this area has been regulated by adequate laws, which differ greatly from one another primarily due to an underdeveloped science-based theory of local development. According to the recently constructed theory, two local planning systems were identified. The first system (of a long-standing tradition) is called the partial system because local and overall social development in a particular country is solely taken care of by a country that has its own development interests. The second (new) system is called the integral system, which implies partner relations between the state and the most influential professional democratic forces that participate in development planning activities. The comparison of these two systems points to the great advantages of the integral system of local planning over the partial one; for this reason, developed countries are increasingly switching to the use of the integral system. Due to the insufficiently developed theory of local planning, this scientific article aims to contribute to supplementing the integral system of local development by projecting its general implications for local selfgovernment and the associated nation-state, as well as the international community. Based on relevant research methods, the obtained results have shown that the implementation of this system implicitly causes positive fundamental social changes which enable less developed countries in particular to catch up with the developed countries much faster and much more efficiently.
\end{abstract}

Key words: local development, integral planning, planning partnership, planning implications, trends, effects

Received October $28^{\text {th }}, 2019 /$ Accepted December $11^{\text {th }}, 2019$

Corresponding author: Igor Vukonjanski, LL.D., Associate Professor, National Academy of Public Administration, Belgrade, Serbia; E-mail: igor.vukonjanski@napa.gov.rs 


\section{INTRODUCTORY NOTES}

Compared to other fields of social sciences, the theory of local and overall social development has evolved significantly more slowly, primarily due to the traditional state monopoly in the field. For this reason, in the newly constituted theory, this system of local planning is called partial system (state-of-interest), which is increasingly inefficient in implementation. In contrast, due to the effects of science and the increasing level of education of the society primarily in developed countries, the first forms of integral local planning system have begun to be applied, which is markedly more vital and effective than the partial system. Its comparative advantages stem from the fact that it uses integral principles and that planning is implemented in partnership by the competent state bodies with the increasing participation of a growing number of social (democratic) forces (scientific, educational, political, economic, environmental, security, etc.).

When it comes to the integral system of local planning, which is increasingly pushing the partial system towards accelerated elimination, it should be noted that this new system is still poorly developed both in theoretical and practical terms. This applies, in particular, to the underdeveloped integrity of this system, to its poorly developed structure (principles, methods, models, computerization, etc.), as well as to the unexplored implications of its application to the local community and society in general, both in the nation-state and at the international level. In such a reality, in many countries (especially the developed ones), the term "integral"1 is increasingly used in local and overall social development planning, without a clear understanding what kind of integration it entails (Radovanović, 2019: 49-56).

This theoretical scientific paper has been developed with the basic aim to fill in the existing "gaps" and advance a theory of integral local and social planning based on scientific tenets and its effective applicability. To this end, this paper is the first attempt to identify the impact of such local and overall social planning on the local community, the nation-state, and the entire global community.

In order to cater for this scientific research, an adequate internal research project was created, in line with the contemporary scientific research methodology, which enabled the collection of relevant theoretical data. Their interpretation should produce certain research results which will contribute to enhancing the scientific knowledge of the integral system of local and social development, and ultimately improve social practice in the field. The research project presented in this paper was structured as follows:

- The research problem came down to the formulation of a basic question that needs to be addressed by research: What is the essence of integral local and overall social planning, and what are the general implications of its application? The research problem thus formulated was the basis for defining all other factors of this research project.

- The purpose of this research was to explore in greater depth and detail the essence of integral local planning and to identify the impact of that planning on the further social developments in the local, national and global social community.

- The research objectives included the intention to deepen the scientific knowledge in the field of new integral local planning, to explore the implications of such an improved planning system, and to increase the practical efficiency of the most important types of social planning;

\footnotetext{
${ }^{1}$ The term "integral" first emerged in the area of social planning at the beginning of the 20th century. However, it was used sproradically and the authors barely explained what it entails.
} 
- The research hypotheses have been set out to be the basic guidelines in solving the set research problem. In this context, the basic research hypothesis is the following view: the intended deepening of the theory of integral local planning will identify in greater detail the components of the integral system, which will form the basis for determining the impact of that planning on the further development of the local, state and global social community.

- The scientific methods used in this research are the general dialectical method, the subject-specific analytical method, and the integral method for individual analysis. On this basis, adequate techniques have been defined and subsequently applied in the collection of relevant research data, which were then interpreted by using the process of inductive and deductive reasoning.

The structure of this scholarly article includes into several parts. The first part of the paper presents the relevant scientific literature dealing with integral local and overall social planning, which was the starting point for identifying the insufficiently examined factors that need to be further and more thoroughly addressed in this research. The second (central) part focuses on the structure and fundamental features of the integral social planning system, which is more comprehensively addressed by using appropriate argumentation and discussing the general social implications for its implementation. The third part deals with the urgency of implementing the integral local planning system, suggesting that the results of this research may be used by developed countries to refine the instituted planning systems, whereas the less developed countries should rapidly introduce integral planning in order to most effectively catch up with the developed countries. The fourth part of the paper identifies and discusses the new scientific knowledge on this matter and new professional achievements resulting thereof. Finally, in the concluding remarks, the author summarizes the basic research findings, pointing to the solution to the posed research problem and the verification of established research hypotheses. The scientific research in this paper is supported by a list of scientific literature, but it has to be noted there is a lack of quantitative research data in the consulted literature due to the fact that the integral planning theory has just been constituted.

\section{THE SCOPE OF THE SCIENTIFIC LITERATURE USED}

In comparison to other fields of social sciences, published scientific literature in the field of local and overall social planning is rather modest in terms of types of available references. As pointed out earlier in this paper, this is a consequence of the long rule of partial planning and the monopoly of the state in this field; for which reason, the establishment of a scientifically based theory of social planning has been lagging behind. This is evidenced by the very small number of published scientific books and a slightly larger number of published scientific articles in the field. ${ }^{2}$ This posed a serious difficulty in selecting the appropriate literature to consult when drafting this scholarly article. An additional difficulty was the author's basic requirement that the scientific literature should deal with the most important segments of integral local planning theory, which are the subject matter of this research: the principles, technology, participants, and implications

\footnotetext{
${ }^{2}$ The small number of published scientific papers of the monograph type in the field of social planning is the consequence of the long traditional, monopolistic role of the state in that planning.
} 
of such planning. In line with this basic requirement, a smaller number of published scientific papers were selected from the consulted subject area literature, which were then were evaluated in relation to the research goals. The assessment results will be presented more specifically in this paper.

Regarding the principles and technology of integral local planning, the authors of the consulted scientific literature ${ }^{3}$ are essentially involved in defining the local planning structures (long-term, medium-term, and short-term plans) and the process of their preparation, but primarily in a professional rather than in a scientific way. Therefore, their works are heterogeneous and rather varied in terms of structure. The same is true of the educational logistics provided for the leading planners and their professional associates (Vukonjanski, 2011: 8-11). The situation is similar when it comes to the holders of the integral local planning; namely, the consulted works in this field ${ }^{4}$ indicate that the partnership between the state authority and the engaged social (democratic) forces has not been addressed in detail in the process of development of these plans and in their critical appraisal by the general public. Accordingly, in the observed works, insufficient consideration was given to the partners' structural cohesion and the further development of their cooperation.

Finally, when it comes to the implications of integral local development, some of the selected authors ${ }^{5}$ emphasize the need for expanding the integral local development to the state and social partnership in all areas of social policy and practice (science, education, economics, ecology, culture and security), but they do not provide a deeper analysis and syntheses on how the initiated state and social partnership would affect the future life of humanity at the local, national and international level. Moreover, scientific literature includes a very small number of scientifically based works where the authors attempted to address the issue more systematically and comprehensively, particularly in terms of the three basic factors of integral local planning (technology, holders, and implications).

This general assessment leads to the conclusion that the basic factors of integral local planning were inadequately explored and theoretically elaborated in the observed scientific literature. For this reason, this scientific paper seeks to adequately fill in the existing gap in theory for the purpose of contributing to the development of a more effective future policy and practice at the local, national and international level. At the same time, it certainly opens the questions of redefining the approach to the current globalization trends, establishing new relations between countries, and establishing a new general integral philosophy which should be further addressed by philosophers, political scientists, sociologists, etc.

\section{INTEGRAL LoCAL PlANNING PROFILE}

Starting from the established research problem and the defined research goals, and relying on the theoretical scope of the consulted scientific literature, it is first necessary to determine the substance of integral local planning, and then to identify and explain the basic social implications of such planning. This task has been undertaken in an endeavour to contribute to a more comprehensive development of the newly constituted theory of

\footnotetext{
${ }^{3}$ Hamdouch, Frank, Rosoolimenesh, Arimaviciuti, Matarrita, Wisley, UN Habitat, Government of Uganda.

${ }^{4}$ Bassand, Nanson, Kovrliouros, Molebatsi

${ }^{5}$ Hirst, Mersal, Subaini, Harrison; Green, Falk; Djordjevic, Filijovic\& Gacic, UNDP.
} 
integral local and social planning and, on that basis, to promote a more effective practice in this field.

When it comes to the substance of integral local planning that is currently being instituted in the developed countries without a more serious scientific basis, we must first clarify the notion of integral local planning, then identify representative structures of the basic types of this planning (long-term, medium-term and short-term plans), and clarify the character of the partnership between the state and social forces in such planning. ${ }^{6}$ Here, we will focus on three most important features of integral local planning, which are essentially characterized (Mersal, 2016: 56-59) as follows:

- In integral local planning, as a scientifically based and most effective approach, the term "integral" has several complementary meanings (Radovanović, 2019: 36-45). The first meaning has an internal character and refers to the fact that it encompasses planning relations and links between all relevant factors of the local community (Wigley, Petiey, 2015: 36-39). The second meaning refers to the external planning linking of local community factors with their environment (other local governments, the state and the relevant international community). Finally, the third meaning relates to the fact that the bearers of local planning are the adequate and competent state authorities and various complementary social organizations (scientific and educational organizations, political parties, various associations, etc.), while all other segments of the covered society may participate in criticizing the prepared local plans and make proposals for their improvement. For this reason, the said creators (bearers) of local planning, together with the involved local organizations and the population, participate in certain aspects of preparation and evaluation of the adopted local plans; thus, local planning has a full integrative character (Arimavčiute, 2011: 124-127);

- In order to be successful, integral local planning must be rooted in appropriate science-based theory. This is especially true when designing the structures of basic local planning (long-term, medium-term and short-term plans). However, due to the aforementioned delays in the creation of such a theory, the initiated integral local planning (primarily in developed countries) is primarily based on the recommendations of the UNCTAD, the European Commission, the World Bank, and some other international organizations that do not have the necessary scientific basis for development planning. For this reason, the applied plan structures are mutually quite different, which is harmful in terms of their quality. Thus, in accordance with the results of previous scientific work in this field, the necessary structures of all basic integral local plans will be briefly outlined. The basic structure of a long-term (strategic) local development plan (for the period of 10 to 15 years) should include the following segments: general community profile; development potential achieved; vision and mission of development; goals and directions of integral development; integral development projects; project effects development; and managing the realization of development (Molebatsi, 2012: 11-13). The basic structure of a medium-term local development plan (from 3 to 4 years) should include the following segments: frameworks and planning sources; selection of development projects for comparison; comparison of selected projects; final

\footnotetext{
${ }^{6}$ The difficulties in addressing this issues have especially arisen from the fact that the published scientific works thus far only incidentally dealt with the substance of integral local planning.
} 
selection of projects; preparation of project documentation; effects of project implementation; financiers of development projects; project realization management (Rasoolimanesh, 2016: 290). Finally, the structure of a short-term plan (for one year) should include: project implementation sequence; project implementation activities; project implementation activities; project evaluation activities; project implementation management. All these activities can be computerized and software programs may be developed as an appropriate tool for collecting and using relevant information to produce these local plans;

- The partnership between the state and society in integral local planning, which has been gradually introduced in the developed countries in recent years, is theoretically complex. It is a consequence of the growing number of highly-educated members of the society who increasingly exert pressure on the state to be actively involved in local community activities, which implicitly leads to the decentralization in managing the public policy and practice in a particular country. This is especially true in the area of local and overall social development planning as the most important segment in the management of society, which then implicitly extends to the society as a whole; ultimately, it contributes to the development of democracy and overall efficiency. When it comes to integral local development, this partnership refers to the formal and organizational involvement of the most competent social forces and state authorities in the development and realization of all plans for integral local development. Such a new reality has huge (even epochal) positive effects on every state and, thus, on the whole world (Frank, 2011:135-138).

Therefore, it can be concluded that the emergence of state and social partnership in integral local planning is a key cause of the democratization in the management of the local government and the society in a particular country, which all leads to the decentralization in the public management as well as in regulating relations in the world as a whole. It is certainly a lengthy process which primarily depends on the level of education in the particular society (state). This process is not strictly timed, and it can ensue at a faster or slower pace, depending on the strength of the democratic forces in each country (Green, 2016:13-16).

When it comes to specific implications of implementing integral local planning in any country, they are numerous and complementary. They are primarily reflected in the management of the local community and the state, the development of science, the dynamics of education, the national economy, environmental protection, social welfare, cultural development, and security. ${ }^{7}$ These implementation issues deserve further consideration:

- The implementation of integral local and overall social development, due to the aforementioned partnership of the state and the society as a whole, will obviously accelerate the process of decentralization in the public management of concrete nation-states, whose bearers will increasingly be the most competent representatives of the state and society. Thus, the public management of the society will gradually move closer to Plato's idea of the state and the experience of the Nordic countries in this area, which imply that the state should be guided by the most intelligent individuals, and which will be enabled by the initiated general partnership of the state and the society in integral local and overall social development. The aggregate results of such social changes have the character of a new developmental era of

\footnotetext{
${ }^{7}$ Due to the poorly addressed essence of integral local planning, the literary literature so far has not discussed in detail the implications of such planning.
} 
humanity, which should be discussed in more detail by leading world philosophers, political scientists, and sociologists (Hamdouch, 2016: 21-22);

- In such a reality, further development of science will play the most significant role. The new scientific content should lead to an advancement of the theory of integral local and overall social development in all fields. In particular, social sciences should pave the way for further development of integral and overall social planning, primarily from the standpoint of further decentralization in public management and the partnership between the state and the society in that process. Thus, we highlight the fundamental impact of education on the development of the society, both at the local and the national level (Harrison, 2001:178-180);

- Accordingly, further development of the level of education of a particular society undoubtedly plays a decisive role in the aforementioned further decentralization and democratization of the partnership-based management of all public policies of each country, which is especially true of the forthcoming (realistically expected) integral local and overall social development. In this regard, it should be reiterated that the level of education of each social community depends directly on its democratic power, which is first reflected in the implicit partnership of the state and social forces in managing a particular country (Bassand, 2001:7-8). This crucial social rule should be constantly taken into account by the leading national and social forces, which should continually insist on raising the level of overall education of the population (Hanson, 2017: 8-10).

In addition, the application of integral local and overall social development planning in the future will have a significant positive impact on the development of all aspects of work and society, especially in the field of economy, ecology, living standard, culture, human security, etc. These issues deserve further consideration:

- The expected future development of countries in the world will have a decisive impact on the development of their national economies. It will be realized through an increasingly constructive attitude of national economies towards further unsustainable penetration of international business and overall globalization in each country. This constructive attitude is primarily related to the use of the positive aspects of international business (growth of gross domestic product and employment rate), and suppressing its negative aspects (striving for reckless use of available natural resources, suppression of national business, etc.). Such future development of national economies must obviously be accompanied by adequate international trade, the further development of which will first move towards organized general freedom of trade that suppresses the accompanying barriers (customs, protectionist and other barriers) (Hirt, Stanilov, 2009: 11-14);

- Similarly, for the sake of sustainability and survival, further development of ecology is expected to move towards improving the protection of all social communities from detrimental impacts that pollute the land, air and water, causing many different hardto-repair negative effects on the local, national and international community as a whole. As all these dangers affect particular countries and the world at large, there is no alternative but to further affirm the separate and joint struggle of all states to preserve the healthy living and working environment in each country and the world as a whole; 
- In such anticipated global movements, nation-states and the international community will have to collaborate and take action to reduce the current large international disparities in the living standard of the population and to protect the most vulnerable members of society in specific national communities (UN Habitat, 2009: 117- 120). This is significant not only for humane reasons but also because it accelerates the economic and social development of each state. Certainly, further development of social protection should be an ongoing process, which will be subject to constant change and refinement;

- Further development of culture, which will be triggered by the expected decentralization of countries and their integral planning and development, will certainly be comprehensive and complex. It will obviously develop towards fostering multiculturalism, which will increasingly move towards affirming a common general culture in all areas as a combination of the most valuable examples of national cultures. This implies the introduction of national and international concern for culture at large, as the cultural heritage of the hitherto life and artistic creation of distinctive parts of humanity and the humankind as a whole (Kourliours, 2013: 4-7);

- Given the anticipated partnership-based public management of the national communities by their state authorities and democratic forces, major and significant changes are likely to occur in the field of security. Namely, although security was largely state-oriented ever since the Westphalian Peace (1648), the attempts aimed at redirecting the focus of security policy towards the well-being of an individual have not gone unnoticed. This is evidenced by the 1994 Report of the United Nations Development Program, which outlines the concept of human security, where humanity is central (UNDP, 1994). On the contrary, some scholars believe that each state is the bearer and the guarantor of the security of its own population and that nothing needs to be changed (Buzan, 2000: 24-27). Such attitudes and the many challenges in the ongoing action of states obviously delay the more frontline implementation of the aforementioned UN concept of human security. However, the expected frontal application of a scientifically-based system of integral planning for local and overall social development removes all obstacles to the affirmation of the concept of human security, as an approach that ensures an increasingly secure and quality life for future generations.

The presented substance of integral local planning and the accompanying implications indicate that this planning is based on the involvement of democratic forces empowered by the high level of education of the population involved in implementing the overall social policy, which was hitherto carried out by the state alone. It is considered to have been the first and most important victory for the democratic forces, which implicitly affects all other areas of life and development of particular states and concurrently causes the decentralization of power in each nation-state (Matarrita, Brannan, 2012: 8-11). In essence, this is a landmark turning point in the further development of all nation-states and humanity as a whole The considerations provided in this paper outline the further (expected) developments in the most important areas of life management and public management. These considerations are intended to point to the major changes that the partnership between the state authorities and the democratic forces will bring in a decentralized public management system; it is obviously a change on an epochal scale which should be further explored by the world's leading philosophers, political scientists 
and sociologists. In view of the newly constituted science-based theory of integral local planning, the research results of this paper tend to contribute to shaping the further development of this theory.

\section{URGENCY OF IMPLEMENTATION OF INTEGRAL PLANNING}

The new theory of integral local planning, which relies on adequate social science and state and social partnership in this, is undoubtedly a revolutionary turn not only in local planning but, consequently, in all other areas of public management of a particular country. It is convincingly more effective than the long-ruling partial (elitist and narrowinterest) state planning. In recent years, due to the strengthening of democratic forces, it has been primarily entering into developed countries, while forms of partial local planning have remained in other countries. Thus, in view of the newly constituted science-based integral local planning theory, all countries should implement it in an organized manner. Yet, in its application, there are serious differences between developed and underdeveloped countries.

Given the requirements of the new theory of integral local planning, the developed countries should first and foremost adequately innovate their legal regulations in the area of local/social planning, then accordingly amend their regulation on the systematic professional development and training of relevant personnel from local self-governments, and entrust the development of their local development plans to appropriate expert organizations in the field. In particular, these activities entail the following tenets and goals:

- Innovation of the legal regulation in the area of local planning implies that it is adapted to the requirements of the newly formed theory of integral local planning, especially in terms of using the designed structures of the basic local development plans (long-term, medium-term and personnel-related plans), and their implementation by means of accompanying computerization and use of relevant software for managing local planning information. In this way, adequate legal regulation on all types of plans and their structures will be ensured in line with the aforementioned theory;

- Improvement of legal regulation on systematic professional development of relevant personnel from local self-governments is essential for their further education in terms of obtaining expert knowledge in the field of integral local planning theory, accompanying computerization and use of software programs for managing local planning information. Thus educated and trained personnel will become important internal associates in the development of all basic plans for the integral development of local self-government. Beyond this, in light of theoretical and legal changes in the field of local planning, these individuals should be required to periodically update their knowledge and skills;

- According to the theory of integral local planning, the development of those plans should in principle be entrusted to expert teams composed of engaged external expert organizations in the field and selected and trained internal planners. External experts should play the role of plan leader in the methodological and integral sense, while the internal planners should cooperate in the concrete design and development of local plans in all their economic, communal and social aspects. It will contribute to creating the necessary professional conditions for developing quality basic local development plans. 
On the other hand, when it comes to less developed countries, their local planning legislation is much weaker than such legislation in the developed countries. Thus, in order to accelerate their transition to integral local planning, it is necessary to urgently implement a suitable program for introducing integral local development in these countries (especially African countries). This project should be entrusted to competent expert organizations. The program should include the design of legal regulations for integrated local planning, the development of an action plan for the implementation of that regulation, and the necessary education of leading experts from those countries for successful implementation of this major undertaking. In particular, these activities should entail as follows:

- the design of legislation for integral local planning should be based on the tenets of that theory, which implies revision of existing (if any) or preparation of new legislation, especially in the area of social planning and professional development of employees in local self-governments;

- on this basis, an action plan for the implementation of this legislation should be prepared, which will elaborate on the participants and method of its implementation, in order to successfully introduce the system of integral local planning in a specific country;

- finally, leading experts from a particular country should be provided relevant professional education and training in order to empower them to be the emissaries of the practical introduction of integral local development in a particular country.

Certainly, all these activities need to be implemented urgently both in developed and less developed countries, given that it has a decisive impact on the dynamics and quality of further development of local governments and the countries to which they belong.

\section{RESEARCH RESULTS AND DISCUSSION}

The interpretation of the research results, based on the inductive and deductive reasoning, has enabled the acquisition of new scientific knowledge related to the field of local and overall social development planning. In particular, it includes the following findings:

1. the overall development of local and social planning in each country directly depends on the level of education of the population involved;

2. partial (state-regulated) system of local/social planning development is suitable for less developed countries, while the integral system is pertinent to more developed countries;

3. the integral system of development is highly more efficient and has high potentials for prospective development, while the partial one is increasingly inefficient and, as such, it will be progressively abandoned;

4. The front-line implementation of integral planning for local and overall social development worldwide will ultimately result in partnership between the state and democratic forces covering all aspects of public management with many major, primarily positive changes (Radovanović, 2019: 22-67). 
These new scientific findings call for brief discussion and concluding observations:

- planning for local and overall social development is indisputably dependent on the level of education of the population involved; thus, in less developed countries with modest education means, it is more suitable to apply a purely state-regulated system; in developed countries, the application of an integral system based on state-democratic partnership is much more appropriate;

- the partial (state-regulated) system of local/social planning corresponds to less developed societies with a lower general level of education, and the integral (statedemocratic) system is more suitable for developed societies with a higher general level of education;

- due to the anticipated further growth of education in the population worldwide and due to the high efficiency of the integral system of social development, this system is highly perspective; on the other hand, due to its lower efficiency, the partial (state-regulated) system must be rapidly eliminated;

- finally, the partnership of state and democratic forces in the field of integral social planning will logically expand to all areas and aspects of public management, which will implicitly cause many major, primarily positive changes in particular countries and in the world at large.

This kind of scientific knowledge contributes to rounding off the theory of local and overall social development planning, and substantiating its scientific grounds and practical efficiency. Thus, the author of this paper hopes for the positive verification of these findings by the relevant scientific public and the social practice.

\section{BASIC CONCLUSIONS}

The presented considerations of the theory and practice of new integral local planning lead to specific conclusions, which will be briefly summarized by highlighting the most important findings of this research paper.

In the introduction of this paper, it was pointed out that the constitution of local planning theory, as a basic part of the entire social planning, was rather slow-paced. The delay was caused by the aspiration of each state to maintain its monopoly position and to change nothing in this area. However, in recent years, owing to the increase in the level of education of the population (especially in developed countries), the democratic forces in these societies have been fighting for partnership with the state in local planning and, to a certain extent, have managed to strengthen their position in the public management of those countries. This was precisely the reason for the ongoing constitution of the scientifically based integral local planning, as a system that is undeniably more effective than the traditional long-standing (elitist and narrow-interest) planning system. All this has led to heterogeneous developments in the theory and practice of local/social planning. Hence, this scientific paper has been primarily aimed at developing the scientific and practical knowledge on this issue and promoting the effective application of this theory.

For the purpose of drafting this paper, an adequate research project was created and implemented, on the basis of the defined research problem and specified research questions: 1) What is the substance of integral local and overall social planning, and what are the general implications of its implementation? 2) What are the general implications of implementing the concept of integral local development? In this context, all other 
conceptual factors of the research were determined (subject, goals, hypotheses and methods), which ultimately served as guidelines for conducting this theoretical research.

Accordingly, the paper first outlines the scope of the researched scientific literature; research results indicate that the existing literature primarily elaborates on recommendations issued by international organizations on how local development plans should be prepared, while only a small section focuses on the scientific reinforcement of this theory. For this reason, this paper focuses on the substance of local and overall social planning and its specific and general implications.

In examining the substance of integral local planning, the paper focuses on the conceptual definition of the "integral" approach, the basic types and internal structures of those plans, and the need for establishing partnership between the state and democratic forces in the process of designing, implementing and evaluating these plans. Notably, the author proposes the use of appropriate models for gathering and managing planning information (registry or software), which would significantly facilitate the preparation and enhance the quality of these plans.

Based on the substance of local/social planning, and especially the infiltration of the observed partnership of state and democratic forces in developed countries, adequate implications of such local and overall social development are projected. They show that this type of partnership, initiated in integral local planning, quickly and easily penetrates all areas of public management, leading to decentralization of states and consequently effecting epochal positive changes in the further development of each country and the humanity as a whole. The introduction of integral local and overall social planning and its implications certainly represent a sort of tectonic change that should be addressed in more detail by philosophy and certain areas of the social sciences.

On the whole, it can be stated that the research problem has been successfully addressed and the postulated research hypotheses have been verified by research results. Considering the significance and the highly positive impact of the initiated partnership between the state and democratic forces in the public management of each country, this paper proposes adequate programs to innovate the initiated integral local planning in developed countries and to accelerate the introduction of such planning in less developed other countries that do not have much experience in implementing such programs. In this context, the research results presented in this paper address important new scientific knowledge related to the substance of integral local planning, the established partnership of state authorities and democratic forces in public management, as well as the revolutionary positive changes that will ensue from these developments. In addition, the paper proposes structural models of all basic local development plans and supporting tools (registry and software) for gathering planning information.

\section{REFERENCES}

Arimavčiute, M., (2011). The Strategic Development Planning for Local Governments, Social Studies, Vol 3, No 1

Bassand, M. (2001). Za obnovu urbane sociologije, 11 teza (For the Restoration of Urban Sociology, 11 Theses), prevod, Sociologija, Vol 43/2001, No 4, Beograd, pp.345-352.

Buzan, B., (2000). "Human Security: What It Means and What It Entails?", Text book Asian-Pacific Round Table, Sydney

Đorđević, I., Filijović, M., Gačić, J., (2017). Bezbednost, ekonomija i održivi razvoj (Security, Economics and Sustainable Development), Fakultet bezbednosti, Beograd 
Falk, R., (1998). Pursuing the quest for human security, Review of International Studies, 24, pp. 4-22.

Frank, D. (2011). City Development Strategy, A Conceptual Framework, Discussion Paper No. 1, World Bank, Washington, DC.

Green, L. N. (2016). Planning Local Economic Development Theory and Practice, Sixth Edition, Sage Piblication

Hamdouch, A., Nyseth, T., Demaziere, Ch., Forde A., Serrano, J., Aarsæth, N. (2016). Creative Approaches to Planning and Local Development, Routlege, Abington

Hanson, R. (2017). Planning Politics and the Public Interest, Comell University Press

Harrison, P. (2001). The genealogy of South Africa's Integrated Development Plan, Third Wordl Planning Review 23(2): 175-193, DOI: 10.3828 / twpr.23.2q4172h26466148n3

Hirt, S., Stanilov, K. (2009). Revisiting urban planning in transitional countries, available at http://www.unhabitat.org/ grhs/ (accessed 10.11.2019)

Kourliours, E., (2013), Local Development and Collaborative Planning, Journal of Regional -Socio-Economic Issues, Vol 3

Matarrita, D., Brannan, M. (2012). Conceptualizing community development in the twenty-first century, Community Development, No 43

Mersal, A. (2016). Sustainable Urban Futures, Procedia Environmental Sciences, New York

Molebatsi, C. (2012). Participatory Development Planning in Botswana, Town and Regional Planning, No2.

Radovanović, T. (2019). Integralno lokalno planiranje (Integrated Local Planning), Visoka škola strukovnih studija za ekonomiju i upravu, Beograd

Rasoolimanesh, S. M., Badarulzaman, N., Jaafar, M. (2016). City Development Strategy: theoretical background, themes, and building blocks. International Journal of Urban Science, 20 (2), 285-297.

Suhaini, Y. (2016). Effectivenese Form and Content of the Local Plan as a Tool for Quality of Life in the Urban Area, Procedia Social, Vol 23

UNDP, (1994). Human Development Report, New York-Oxford: Oxford University Press

UN Habitat (2009). Planning Sustainable Cities, UN, New York

Vukonjanski, I (2011). Novi javni menadžment i ljudski resursi u jedinicama lokalne samouprave Republike Srbije (New Public Management and Human Resources in the Local Self-Government Units of the Republic of Serbia), Radnička štampa, Beograd

Wigley, M., Petriey, T. (2015). Integrated Development, FHI 360

\section{SUŠTINA I IMPLIKACIJE INTEGRALNOG PLANIRANJA U JEDINICAMA LOKALNE SAMOUPRAVE}

Planiranje lokalnog razvoja u jedinicama lokalne samouprave (opštinama i gradovima) u svim zemljama oduvek je imalo važnu društvenu ulogu. Upravo zato se ta oblast poslednjih decenija reguliše adekvatnim zakonima, koji se međusobno veoma razlikuju prvenstveno zbog nedovoljno razvijene naučno zasnovane teorije lokalnog razvoja. Po toj tek konstituisanoj prvoj viziji teorije, s razlogom su identifikovana dva sistema lokalnog planiranja. Prvi sistem, sa dugom tradicijom, nazvan je parcijalnim sistemom zato što o lokalnom i ukupnom društvenom razvoju u konkretnoj zemlji isključivo brine država sa svojim razvojnim interesima. Drugi, novi sistem se zove integralni sistem u kojem partnerski učestvuju država i najuticajnije stručne demokratske snage koje su se za takvu ulogu izborile. Njihova međusobna komparacija ukazuje na krupne prednosti integralnog u odnosu na pracijalni sistem lokalnog planiranja, pa se zato naročito u razvijenim zemljama, s razlogom sve više prelazi na korišćenje integralnog sistema. U tome, naročito zbog nedovoljno razvijene teorije lokalnog planiranja, prišlo se izradi ovog naučnog rada, sa ciljem da on svojim rezultatima doprinese dopunjavanju integralnog sistema lokalnog razvoja sa projektovanjem njegovih opštih implikacija na lokalnu samoupravu i pripadajuću nacionalnu državu, kao i međunarodnu zajednicu. U radu su korišćene adekvatne metode istraživanja, a dobijeni rezultati su pokazali da se primenom ovog sistema implicitno izazivaju pozitivne funadamentalne društvene promene koje, naročito manje razvijenim zemljama, omogućuju brže i efikasnije sustizanje razvijenih zemalja.

Ključne reči: lokalni razvoj, integralno planiranje, plansko partnerstvo, planske implikacije, trendovi, efekti 